\title{
Structures of Irony: Curiosity and Fetishism in Late Imperial London
}

\section{GEORGE MICAJAH PHILLIPS}

London, that wonder city, the growth of which bears no sign of intelligent design, but many traces of freakishly sombre phantasy.

\author{
Joseph Conrad, "Poland Revisited"
}

You can make India in England apparently, just as you can make England in India.

E. M. Forster, A Passage to India

This essay seeks to understand one way in which modernist fiction responds to Britain's metropolis as contact zone. I ask what can be learned from the detachment that two of modernism's best-known ironists, Joseph Conrad and E. M. Forster, cultivate in their responses to early-twentieth-century London. Specifically, I ask: What happens when we read Conrad's novel The Secret Agent (1907) and Forster's exhibition review, "The Birth of an Empire" (1924), as ironic responses to London as they knew it? And what further responses might those texts call for now? Setting, then, will figure prominently here, but equally significant will be visual metaphors of space and structure that abet irony's role in these texts. I argue that Conrad's attention to what he calls London's endless vistas-the windows, doors, and apertures that could mark points of passage but in Conrad tend instead to be sealed thresholds between spaces-enables a presentation of London as an imperial capital so needful of its colonial entanglements for its own identity as to warrant the powerful ironic distancing found in The Secret Agent. Often recognized as a high achievement of modernist irony, The Secret Agent in fact goes further, inviting its readers to trace the limits of irony as a responsive (and responsible) style.

Tracing those limits as closely tied to Conrad's confrontation with London's endless vistas will put us in a better position to understand how Forster deploys irony while asserting the metaphorics of circulation within and between intimate spaces, resulting in a strategy of ironic detachment from metropolitan imperial culture that seeks productive forms of reattachment. Conrad's impenetrable vistas and Forster's hospitable locations-the structures of irony of my title-prove to be spaces designed for ironic presentation that also disclose the role of curiosity as irony's dialectic shadow. In The Secret Agent, curiosity is the element whose conspicuous absence burdens irony with the obligation to respond alone to the

I am grateful to Jonathan Allison and Jonathan Sircy for their immensely helpful comments on earlier drafts of this essay. 
late imperial culture Conrad characterizes as governed by fetishism. By contrast, curiosity appears in Forster's review not as irony's naive opposite but as that which learns from the distance irony produces and as the occasion for testing tentative styles of reattachment to the metropole. ${ }^{1}$

\section{Modernist Irony and Colonial Exhibitions}

Of the myriad expressions of London's global reach in the early twentieth century, Forster responds expressly to the "high imperial vision" of colonial exhibitions ("Birth" 44). The Secret Agent, too, demands to be approached in this vein, setting itself against the fascination with pseudoscientific narratives that colonial exhibitions helped to popularize. ${ }^{2}$ Recent work in modernist studies also invites us to be attentive to colonial exhibitions in order to understand London's modernism as emerging from a city that was the British Empire's cultural and economic center and one of its contested locations. ${ }^{3}$ One could productively read literary modernism, as Scott Cohen does, as responding to the spatial and geographical conditions of colonial exhibitions. But this approach may overlook the significance of visuality in the development of metropolitan modernism. Taking a different tack, Andrew Thacker describes the displays, exhibits, and the gazes they inspire as rendering colonial exhibitions "visual contact zone[s]" (33). The close attention Forster and Conrad turn toward the processes of sight and the conditions of space calls for just such a model that regards visual experiences at exhibitions as mediating "the spatial and temporal copresence of subjects previously separated by geographic and historical disjunctures, and whose trajectories now intersect" that defines a contact zone (Pratt 7). ${ }^{4}$

1 As a category of inquiry, curiosity tends to be pursued in relation to Renaissance literature and culture (see, for example, Benedict and Stagl) but is largely ignored in relation to modernity. A fantastic exception is Ross Posnock's study of the James brothers in The Trial of Curiosity. Part of my aim here is to pursue an alternative knowledge of curiosity's role in response by considering it within the paradigm of modernist irony where, I argue, it appears as a "reparative" device in Eve Sedgwick's sense of that term, a tactic that can "surrender the knowing, anxious, paranoid" position for one that finds it "necessary to experience surprise" (146).

2 Joseph McLaughlin's excellent reading of The Secret Agent regards it as most properly belonging to a metropolitan scene in which colonial exhibitions figure prominently (see especially 154-55). So, too, do I want to restore The Secret Agent to just such a context in order to measure its response to a city that sometimes seemed "a frontier space ... an urban heart of darkness" $(20,23)$.

3 In addition to those cited above, see Kurt Koenigsberger (149-81) and Mark Wollaeger (Modernism 71-119).

4 But the modifier visual before contact zone may be redundant. Though the notion of the contact zone has been particularly useful to approaches that consider the geographical conditions and spaces that literature addresses, we do well to recall that vision was a significant component of Mary Louise Pratt's conception of contact zones. Her approach in Imperial Eyes leads to reconsiderations of "what in European culture counts as a purely passive experience-that of seeing" (204). 
In the decades surrounding 1900, tens of thousands of Londoners annually invited such intersections by devoting immense segments of their capital to the colonial imaginary. Exhibition guidebooks make it clear that exhibitors sought to satisfy a widespread desire to publicly display systems for classifying and representing the vastly diverse peoples, territories, and commodities that appeared under the sign of Empire. At a time "when the gospel of Imperialism is being so widely preached and when men's minds are naturally interested in records of national achievement and the statistics of national progress," reasons the author of an 1899 exhibition guide, the era enjoins "a colossal and comprehensive display of the growth and development of the British Empire" (District Railway 10). Here the guide discloses a common feature of colonial exhibitions: their attempts to cater to, and drum up, curiosity for empire's stories and to manage that curiosity with displays and guidebook narratives. Though Walter Benjamin famously declared that exhibitions succeeded in funneling visitors' curiosity to "places of pilgrimage to the commodity fetish" (7), they did more than dupe the feebleminded: colonial exhibitions also introduced their spectators to a quasi-scientific method for interpreting alterity that coincided with the pleasures of purchasing souvenirs (such as official handbooks) at the event. If we imagine exhibition visitors as subjects enmeshed in prefabricated conditions but also involved in the construction and reconstruction of those conditions, we might say these visitors arrived at Earls Court and Olympia precisely in order to enter spaces where the colonial world could be visually consumed in tidy, orderly displays. ${ }^{5}$ These displays invited a detached scientific gaze that does not empathize with who or what one looks upon but instead encourages exhibition visitors to imagine themselves as something like amateur social scientists touring in the colonies.

As a result, although commodity display and consumer culture figure prominently in London exhibition culture, it might be misleading to follow Benjamin in speaking of the gaze colonial exhibitions solicit in terms of commodity fetishism. That term proves too coarse a sieve for sorting out the complexities of exhibition culture. We may be better off with the more general understanding of fetishism that had wider currency among Victorians and Edwardians than either commodity fetishism or nascent theories of sexual fetishism. ${ }^{6}$ As Peter Logan explains, throughout the second half of the nineteenth century and for at least the first decade of the twentieth, fetishism was as significant for its connotation as for its denotation. It denoted the act of projecting agency onto an inanimate object and connoted savagery, primitivism, and all that was alleged to be part of cultures that practiced religious fetishism-that is, all that was counter to the idea of civilized, enlightened society. "During these years," writes Logan, "fetishism defined ideas about culture through difference, not by describing what [culture] was but

5 The social theorist Anthony Giddens, who calls such subjects "knowledgeable agents," masterfully explains this rich sense of being in the world (54).

6 Though sexologists began theorizing fetishism in the nineteenth century, not until 1927 (two years after London's final colonial exhibition) did Sigmund Freud's theory of sexual fetishism appear. 
by defining what it was not" (4). ${ }^{7}$ These associations began attaching to fetishism in the mid-nineteenth century owing in no small part to the Great Exhibition held in London's Crystal Palace in 1851. Though exhibitions were not new to Victorians, the Great Exhibition offered an unprecedented display of cultural artifacts and people that intended to represent the entire world for the purpose of cultural comparison. Not incidentally, the terms of that comparison-demonstrations of scientific and technological advancement-were arranged so that British culture clearly surpassed all the rest. Visitors walked through passageways and corridors that followed a teleological narrative of cultural progress that "emphasized the place of Britain's culture in the overall range of advancement" (5). This model of visual comparison was not only supremely successful but also powerfully influential for British exhibitions in the decades that followed. Nearly sixty years later, the Imperial International Exhibition held in London in 1909 measured itself against "the great exhibition of 1851, which was virtually the parent of these undertakings," by seeking cultural comparisons again in terms of scientific advancement. "In those mid-Victorian days, science, as it is understood to-day, was in its infancy; application of electricity to illumination was unknown," the official guidebook explains (Imperial 2). This guidebook reproduces a familiar narrative of colonial exhibition culture. The brisk pace of "the milestones of progress" in Britain since 1851 explains the accumulation, arrangement, and array of that country's machinery, textiles, and domestic products, all of which are placed among "the choicest products of the earth ... for our inspection" $(2,3){ }^{8}$

This exhibition aesthetic, which lays claim to direct presentation as a means of cultivating knowledge about the observable world, finds its opposite in modernism's self-reflexivity, fragmentation, and ironic detachment. In tracking the changes in European social life and literary history over the course of empire's expansion and contraction, Edward Said has noted that disenchantment with empire reached critical mass just as irony was being granted unprecedented authority as a style of response toward European metropolitan culture. This is the irony endemic to modernism, "the irony of a form that draws attention to itself as substituting art and its creations for the once-possible synthesis of the world empires" (189). The purpose of submitting an aesthetic solution for political problems is, of course, to produce new knowledge about the nature of those problems, distancing and depersonalizing them so that they may be contemplated anew. In order to respond to London as a visual contact zone that colonial exhibitions helped to produce, it made sense for modernism to build on the irony that had become central to nineteenth-century realism. If modernism's ironists were to reorder the world in new views from imagined spaces, they would need to seize upon a device "within

$7 \quad$ As Logan notes, the Encyclopedia Britannica defined fetishism in 1911 not in terms of economics or sexology but as a practice that exists outside of culture. And though the term soon became controversial, fetishism in this sense continued to circulate in evolutionary anthropology and ethnography as late as 1925 (6).

8 The 1909 Imperial International Exhibition took the comparison a step further by recreating a village in the West African kingdom of Dahomey, an exhibit that imported African fetishists as well as fetishes. 
which everything is seen as many-sided" (Lukács 75). Georg Lukács found the recompense of irony to be a view "within which things appear as isolated and yet connected, as full of value and yet totally devoid of it, as abstract fragments and as concrete autonomous life, as flowering and as decaying, as the infliction of suffering and as suffering itself" (75).

The shift from realist to modernist irony resulted partly from a change in how each generation approached perception, particularly sight. Fredric Jameson offers a helpful articulation of this transition in judging the turn of the twentieth century as a moment in which authors were reevaluating how literary aesthetics is "dependent on the very ideology of the image and sense perception and the whole positivist pseudo-scientific myth of the functioning of the mind and the senses" (212). Modernist texts present immediate sense information, particularly visual information, without paying tribute to explanatory theoretical frameworks, in this way deepening a broader skepticism of metanarratives that will be amplified in the latter half of the century. In The Political Unconscious Jameson also explains that modernism's response to its culture emerges not only from a place of irony but from wonder and curiosity as well. For a writer like Conrad, the reluctance to accept grand "positivist pseudo-scientific" theories of perception meant "a rejection of the conceptual in favor of the two great naturalist psychic and narrative texts of daydreaming and hallucination. Where Conrad marks an 'advance,' if that is the right term to use about this historical process, is in his own mesmerization by such images and such daydreaming" (212-13; emphasis added).

Pursuing a finer history of this moment requires us to understand what might be meant here by "mesmerization." To be mesmerized may mean to be deeply enthralled by a work of art, subject, or event: to give oneself over to fascination for something absorbing or difficult. But it may also mean (as it did during the period in question) to be hypnotized, to be locked into conditions of perception dictated by another. Jameson's phrasing preserves both readings, allowing modernism to issue from deep self-awareness of the visual grammar of compelling spectacles as well as from writing from within their grip. But let us divide these experiences into "curiosity"-meaning an approach that self-consciously seeks attachment with something or someone else-and "fetishism"-meaning an approach that seeks such attachments unself-consciously, indeed unknowingly.

Exploring modernism as emerging from the fetishism and curiosity I take as residing within a mesmerization of images allows for a fuller understanding of how Conrad's treatment of reveries in London and Forster's daydream at a colonial exhibition each sound the limits of irony as a counterstrategy against a culture saturated with spectacles of progress in the form of imperial dominance and scientific advancement. Irony begins a responsible stance toward the late imperial metropole by seeking to draw knowledge out of metropolitan spectacles through procedures of distance and disidentification. Yet irony must also sometimes remain a partial alternative that cannot reengage with the flawed object of its critique. For Forster and Conrad alike, the wound a knowing irony inflicts on London's spectacles is incomplete without a device that allows for the unexpected reattachments that tend to develop in irony's wake. Curiosity may serve as irony's accessory in 
this very way, making possible a much broader and richer response to a culture of fetishized spectacles than either irony or curiosity could alone.

\section{The View from Conrad's Windows}

On the first page of The Secret Agent Adolf Verloc leaves his home, which is also the pornography shop he runs with his wife, Winnie, and brother-in-law, Stevie: "Mr. Verloc, going out in the morning, left his shop nominally in charge of his brother-in-law" (3). But this turns out to be something of a false start. Not until the beginning of the second chapter, when we begin to follow Verloc on his journey away from home and to an unspecified eastern European embassy- "Such was the house, the household, and the business Mr. Verloc left behind him on his way westward at the hour of half past ten in the morning" (10)_-does the novel begin in earnest. This double opening allows Conrad to provide necessary background for Verloc's story right away and perhaps serves as an elementary instance of what Ian Watt called Conrad's delayed decoding (175). More importantly, this return to the beginning initiates a pattern of repetition and obsession that will become familiar over the course of the novel. It will be invoked each time Verloc and Stevie leave and return from their walks through Greenwich Park to their Brett Street home; in the visits made by Chief Inspector Heat and the assistant commissioner of police to the Verlocs' shop after the bomb attack; and once more when Winnie returns with Comrade Ossipon to the Verlocs' home after she has murdered her husband. Moreover, as the murder of Adolf Verloc reveals, such obsessive returnings focus not only on locations but on visual information as well. Only when Winnie "thought in images" was she also "governed too much by a fixed idea" that leads her to murder her husband $(204,215)$.

Just such patterns of repetition and obsession concern Vladimir, the embassy official who has summoned Verloc away from his home and shop on the morning the novel begins. Vladimir has called upon the failed agent provocateur so that he may provide Verloc with a scheme that could believably be pinned on zealous antigovernment insurgents. "You anarchists," Vladimir bristles, "should make it clear that you are perfectly determined to make a clean sweep of the whole social creation. But how to get that appallingly absurd notion into the heads of the middle classes so that there should be no mistake? That's the question" (27). To that question Vladimir offers a reasoned reply: the target must be unthinkable, not heads of state, houses of worship, theaters, public squares-for all these have been rendered cliché by "ready-made phrases [used] to explain such manifestations away" - but instead "something outside the ordinary passions of humanity" (27). This reasoned argument, it turns out, targets reason itself: "What is the fetish of the hour that all the bourgeoisie recognise-eh Mr. Verloc? ... The sacrosanct fetish of today is science. Why don't you get some of your friends to go for that wooden-faced panjandrum-eh?" $(25,26)$.

That Conrad's anarchists and counterrevolutionary plotters should respond to London in the language of fetishism is not particularly surprising. Nor it is surprising that The Secret Agent should itself conduct its response under the maneuvers of irony that reveal anarchist plots against London's fetishes to be "hopelessly futile," 
as Conrad was fond of calling them (43; cf. xxxv). More noteworthy is that Conrad's ironic narrative procedures should so closely approximate the obsession, repetition, and visual fascination Vladimir attributes to London's bourgeoisie. If readers of The Secret Agent have not taken note of this before, perhaps this is because the novel's "thick fog of irony," as Irving Howe had it (96), is so thick that it impedes the very readings of the culture to which the novel addresses itself, leaving irony to be treated as a theme in its own right rather than as a mode of response. This despite the fact that even its author insisted that the novel can be "traced to a period of mental and emotional reaction" to "feel[ing] . . . lost in a world of other, of inferior, values" (Secret xxxiii, xxxv). As "a perfect illustration of the ironic theme" (Spector 166), The Secret Agent throws one of irony's tendencies into high relief: namely that when its distancing operations work most efficiently irony can seem an aesthetic of self-enclosure. But we would do well to press on this aesthetic. As Amanda Anderson reminds us, "[D]etachment, whatever form it takes or predominantly allies itself with, is always situated-it is always a detachment from a particular mode of experience, a social situation, or a form of identity" (175). The trouble The Secret Agent gives readers who wish to regard it as a response to its situation is twofold. First, how does this novel suggest that the concept of fetishism is circulating in turn-of-the-century London? Second, what can the novel's detachment and relentless repositioning from the Londoners who populate Conrad's narrative tell us about irony as a mode of response?

Directed not only at the broad category of "science" but specifically at the Greenwich Observatory, the language of fetishism in The Secret Agent posits fetishism as the fixations with and attachments to technologies of colonial domination (the observational knowledge that in different ways undergirds cartography, topography, and institutionalized racism) as well as the disavowed knowledge of how investments in the colonies produce domestic wealth ("Any imbecile that has got an income believes in [science]. He does not know why, but he believes it matters somehow," Vladimir declares [27]). In Conrad's African fiction, fetishism proves to be European modernity's colonial unconscious. Reading Heart of Darkness (1899), Simon Gikandi argues that fetishism goes unnamed throughout that text precisely because of its powerful hold over Marlow. Unable to decouple his European subjectivity from his African locality, the fundamental narrative act of arranging events sequentially - "the enabling condition of epistemology and consciousness in the Western tradition"-fails, and ultimately "temporality in Heart of Darkness is haunted by fetishism, which the narrative compels to function as the radical opposite of knowledge and consciousness" (176). Written within a decade of Heart of Darkness, The Secret Agent is heir to the same conflicts of colonial contact but is also far more aware of its fetishistic design, making its center not an ungovernable, unknowable alterity but the West's fetishization of science itself. "Science" here denotes little more than the thinnest veil of scientific evidence conveniently laid over a predetermined politics, much like the Lombrosoism embraced by Comrade Ossipon or science as it was displayed at colonial exhibitions. If the Greenwich Observatory emerges in this text as London's fetish for "learning-science," as Vladimir says (Secret 28), its fetishists would doubtless have patronized the annual extravaganzas that offered "a spectacle constituted as simultaneously scientific 
exegesis and as mass entertainment" (Coombes 63) held in west London between 1886 and 1925, a time encompassing the novel's 1894 setting and the 1906-7 period during which Conrad composed and published The Secret Agent. It is precisely London's exhibition culture, and the fetishistic modes of seeing that it encourages, that provide the most productive basis for understanding The Secret Agent's ironic posturing.

Against the annual events Paul Greenhalgh calls ephemeral vistas are the vistas embedded in The Secret Agent. During the scene in which Vladimir unfurls his plot to destroy the observatory, Verloc elects to demonstrate his authority by opening a window and calling out to a distant policeman on the street. But what is meant to be a show of Verloc's "usefulness" (Secret 20) Vladimir dismisses by explaining that Verloc's action, not his voice, is required of him. In the context of the novel, the significance of this dismissal lies less in this distinction between action and words than in the kind of action Verloc's words have failed to perform. Verloc succeeds in startling the constable down the street, but his own situation does not change; he remains inside the embassy awaiting Vladimir's instructions. Such moments recur throughout The Secret Agent-so often, in fact, that it would not be difficult to find among the novel's obsessive patterns similar scenes in which characters approach openings that promise emancipation only to discover themselves circumscribed once more. This reading would begin with the novel's first vista, the Verlocs' shop window, which does not entice with glitzy identity-enhancing products but offers only dimly lit "nondescript packages," "closed yellow paper envelopes" (3), and other "nondescript things" (124), a window that lights onto "the comfort of obscurity, not the seduction of display," as Rishona Zimring reads it (334). The pattern proceeds to Verloc's interview at the embassy and his return home to Soho, where other "windows shone with a dark opaque lustre" (Secret 12). That night Verloc will watch the reflection in his bedroom window transform into a terrifying vision of Vladimir's face, "a sort of pink seal impressed on the fatal darkness" outside (47). Standing before the same window after she learns of Stevie's death, Winnie will discover that her "freedom" exists in name only (208). At last we would arrive at the final vista to appear in the novel: the open space atop the cross-channel steamer from which Winnie, full of "furious anguish," throws herself (251).

Repeated encounters with portals that promise access only to present obstruction instead seem as much a part of Conrad's sense of the city in which he wrote as features of his novel. When Conrad returned to The Secret Agent to write his author's note in 1920 he explained the process of writing the novel as at once ignited by his fascination with London and inhibited by the responsibility of writing such a vast space: "Irresistibly the town became the background for the ensuing period of deep and tentative meditations. Endless vistas opened before me in various directions. It would take years to find the right way! It seemed to take years! . . " (xxxvii; ellipsis in original). To be sure, generations of scholarship have found Conrad's retrospective reconstruction of writing The Secret Agent to be imperfect, but, as Geoffrey Galt Harpham argues, the author's note reveals Conrad's sense of the act of composition, an act he situates throughout this text as closely associated with the dynamism of London itself. If we can read "endless vistas" as Conrad's metaphor for "infinite possibilities," the problem of writing the swelling and heterogeneous 
metropole seems quite similar to the problem exhibition visitors reported whenever they sought to record all that they saw there. "Who can describe that astounding spectacle?" asked one visitor to the Crystal Palace in 1851. "Lost in a sense of what it is, who can think what it is like?" (qtd. in Hoffenberg xx). In the context of Conrad's author's note, these questions raise others. What are the consequences of setting a novel amid London's appetite for overwhelming spectacles that the Great Exhibition inaugurates? How do we read Conrad's report that the very feature that inspires his curiosity about London-the city's seemingly ceaseless variety of singularities-is also what makes it a daunting setting for works of fiction? Finally, what are the consequences of figuring London's heterogeneity as "endless vistas" in a novel whose vistas unflaggingly curb, confine, and close down?

These questions presume that exhibitions disclose a great deal about the cities they host, a premise that can be traced at least as far back as Conrad's German contemporary, Georg Simmel. Simmel understood exhibitions as the constructions of a collective sense of how a metropole wished to imagine its place within a global scheme. As he put it in 1896, one of an exhibition's purposes lies in demonstrating that "a city can represent itself as a copy and a sample of the manufacturing forces of world culture." "Nowhere else," Simmel continues, "is such a richness of different impressions brought together so that overall there seems to be an outward unity, whereas underneath a vigorous interaction produces mutual contrasts, intensification and lack of relatedness" (256). More recently, Timothy Mitchell's penetrating analysis of exhibition culture explained that exhibitions impose a sense of unity over culturally disparate materials in much the same way that cities fashion their sense of identity. "Exhibitions were coming to resemble the commercial machinery of the rest of the city. This machinery, in turn, was rapidly changing in places such as London and Paris, to imitate the architecture and technique of the exhibition" (299). If, as Mitchell suggests, exhibition-going was becoming more like city-strolling as the nineteenth century drew to its close, it is not surprising that both activities were represented according to the same logic. The exhibitions' maps, placards, guidebooks, and the narratives cued by scientific displays suggest that the city outside may be organized along the same lines, creating what Mitchell calls "the world organized and grasped as though it were an exhibition" (296). According to this argument, the infrastructure of exhibitions forms a system of accessibility that can be more widely applied: the diverse spaces of London can themselves be imagined, mapped, and experienced as if they were part of an exhibition. But what seems at first to offer a universally applicable system of signs for comprehending globalizing modernity soon seems far more stifling because the system of signs must be maintained even where maps, placards, guidebooks, and scientific narratives are unavailable. Just as the sprawling exhibitions themselves made it difficult for exhibition-goers to find their way out, the reality effect produced by the exhibition genre also encloses. The city and exhibition alike appear "organized as a system of commodities, values, meanings, and representations, forming signs that reflect one another in a labyrinth without exits" (300). The taxonomized presentation of heterogeneous global contents that had made the exhibitions commercially successful in the first place also exposed them to the same girded, autoreferential limits of any representational system of signs. 
The Secret Agent conducts its critique of London along these lines, detaching itself from an urban reality effect to reveal that aesthetic to be dominated by popular constructions of science and spectacles of imperial metropolitan culture. Put another way, what secures characters' access to the real are also, by necessity, the agents of fetishism. In winding the circle of metropolitan imperial culture as tightly as it can, The Secret Agent discloses an essential fact about discourses of fetishism. When modern western thinkers interpellate fetishism as such, they do so partly in order to distance themselves from fetishistic thinking, seeing, and material relations - and yet acts of fetishism remain acts that modern rationality represses but can never entirely banish. When Vladimir locates London's sacrosanct fetish in the Greenwich Observatory, he reveals not just that this building and the scientific practices for which the institution stands have been fetishizedthe same scientific practices exhibitors deploy to assert western cultural dominance over animist cultures-but that the tendency to fetishize representational systems may govern more forms of modern seeing and thinking than we sometimes realize. Indeed, as The Secret Agent confirms many times over, Edwardian London became a city of vistas that promised scientific and cultural advancement but that more readily revealed a deep obsession with displays and narratives that promise scientific and cultural advancement. In such a frame where representation itself cannot be trusted but must be relied upon nonetheless, Conrad's novel pursues a self-conscious technique of distancing from cultural values that means to call into question the self-aggrandizing distancing from "primitive" cultures that characterizes the fetishism of science found in the exhibitions. To engage any further with this culture, Conrad suggests, would be irresponsible. Rather than affirming any value or value system found in this London, what The Secret Agent instead most cherishes are the countervaluations-distance, detachment, and the disengagement that calls all else into question-of irony itself.

But, one wants to ask, aren't there always possibilities for renewed engagement, even in a narrative space as constricted as The Secret Agent? There are in fact a handful of moments in which Conrad's characters find themselves under the spell not of fetishism but of curiosity. The best case to take up would be the unnamed "lady patroness of Michaelis" (86), the one character in The Secret Agent expressly described as "curious at heart" (87). The assistant commissioner recalls this patron fondly, having been a frequent guest of the drawing room she has lately been providing for Michaelis (a benign and recently paroled anarchist, also called "the ticket-of-leave apostle" [89]) to write his autobiography. As a "temple of an old woman's not ignoble curiosity," the patron's drawing room has been fashioned into something resembling an exhibition space where at a given gathering one could observe and mingle with the "notabilities and even the simple notorieties of the day" (87). And an exhibition space it has become, for on the day the assistant commissioner recalls, he stood in her drawing room among "groups of people" and "beheld the ticket-of-leave apostle filling a privileged armchair," at work on his autobiography "in semi-privacy within the faded blue silk and gilt frame screen ... in the light of six tall windows" $(87,89,87)$.

Why an aristocratic socialite should turn her curiosity, and her patronage, toward an anarchist who prophesies the end of wealth, the narrator reports, owes 
to the "lofty simplicity" of her class, the very quality that makes her curiosity possible (87). The patron's, then, is an empty curiosity, merely a means of preserving her reputation as a worldly personality whose other use for her drawing room is to pontificate on the scandal of the moment (such as the circumstances of Michaelis's imprisonment) before "banal society smiles" (91). While one is tempted to assign more significance to the curiosity of the novel's detectives, the patron's disingenuous curiosity actually reappears in the register of police detection. ${ }^{9}$ Like Chief Inspector Heat, whose interest in surveying London's underworld is largely only a safeguard for his proud professional reputation, and like the assistant commissioner, for whom metropolitan detective work is most interesting when it reminds him of "tracking and breaking up certain nefarious secret societies" in the unnamed colony where his career began (82), Michaelis's patron cares less about his politics than the controversy his presence in her drawing room is sure to stir. In short, curiosity surfaces in The Secret Agent only to be co-opted by the fetishizing gaze prompted by exhibition display. Rather than providing a point of departure for inquiries that may fracture disciplining social practices, curiosity merges with fetishism under the genre of exhibition display that has been arranged in the patron's drawing room.

Vladimir's instruction to marshal an attack "against learning-science" (28) turns out to express a close association between the apparent acquisition of knowledge and the actual reaffirmation of staid positions and perceptions. The absence of genuine curiosity in this narrative reflects the sense that London has been closed off, a massive labyrinth without exits that completes the reciprocal relation Mitchell identifies between cities and exhibitions. Where Karl Marx was able to formulate a theory of commodity fetishism by examining London's capitalist production from numerous perspectives-moving quickly, as David Harvey puts it, "from one 'window' to another in the first chapter of Capital" (16)-Conrad encountered just such a continuous chain of vistas in London only to feel the delirious sense that none open after all and that the only way to access London was through ironic, multiperspectival presentation. Though he avers that he was finally able to write the novel after he could imagine the city "reduced to manageable proportions" (Secret xxxvii), it seems more apt to say that Conrad simply displaced the problem of London's endless vistas into the narrative itself, and with it the problem of the indeterminacies of curiosity for which those endless vistas stood. Generations of critique bear this out. Irving Howe, the first to offer a powerful and nuanced reading of the irony in The Secret Agent, felt that the novel "forces one to conclude" that "irony has turned in upon itself" (96), and for all the revaluations Howe's reading has received, professional readers in the half century since have only sharpened the sense of claustrophobia he attributes to Conrad's irony. For Mark Conroy, The

9 Rebecca Walkowitz, for one, writes that The Secret Agent "presents 'curiosity' as a crucial attribute of both spies and of detectives" (49). But while this emancipatory sense of curiositywhich, for Walkowitz, culminates when detectives and others recognize "belonging as a social process" (37) - aids Walkowitz in an important reading of modernist culture, this use of the term curiosity strikes me as differing widely from what the novel means by the "curiosity" of the patron and detectives. 
Secret Agent shades forth a London designed according to a panoptic scheme. For Joseph McLaughlin, Conrad's characters find their way into seductive metropolitan spaces only to discover that they cannot escape, for "Conrad offers no sense of an outside to this commodity culture" (163). Similarly, for Mark Wollaeger, to read Conrad's "harsh ironies at the characters' expense" is to encounter characters "imprisoned" within a monologic dark comedy (Joseph Conrad 145, 163).

Yet the yearning for an outside that so often comes with reading The Secret Agent is not the novel's limit point, and what sounds at first like a bleak Frankfurt School-style assessment avant la lettre turns out to be something more. As we have already begun to see, this narrative incites readers to feel curiosity's absence acutely, for it is by reading a London where curiosity seems impossible that we may come to appreciate its value. That value lies nested within the novel's irony and can be extracted only by readings (like those I have just mentioned) that point bidirectionally: toward the limits of irony as a responsible way of seeing the fetishes that adorn Conrad's London, and toward the productive powers of curiosity. Rebecca Walkowitz articulates perhaps the most enduring lesson that The Secret Agent's irony can yield: "that interpretation is limited by the meanings that characters and readers are able to recognize" (49). If what one recognizes is detachment itself, it becomes deeply important to read this detachment as a limited response. Not doing so is tantamount to Chief Inspector Heat's mistaking Winnie's ignorance of the observatory bombing for her "detachment" from his questions, a detachment that "whetted his curiosity" for what he erroneously imagines she is withholding (167). That these characters fail to rise to the possibilities inherent in curiosity only serves to place the burden more heavily on readers, as the critics I have just mentioned know all too well.

That burden can be characterized in this way. Conrad not only affirms in the author's note that "perverse unreason has its own logical processes" (xxxv); the narrative of widespread fetishism that follows also reveals that unreason exercises its secret agency over a world from which one cannot retreat. Instead, one must find tactics for working from within. Irony is one such tactic, but curiosity emerges here as another, a shadow partner to irony itself. As Conrad's narrator has it, "[c]uriosity" is "one of the forms of self-revelation" (194), a responsive mode whose revelations about oneself and one's culture can supplement irony's lessons. Conrad's response to London in the heyday of colonial exhibition culture would certainly have qualified as the modernist response Said explained as structured "not oppositionally but ironically, and with a desperate attempt at a new inclusiveness" (189). That is, Conrad's is a resisting response but not a chiding one. Enunciations that wish simply to close down the reprehensible not only repeat the violence of the past by revisiting and reiterating it; in passing once more by the ghastly only to condemn it, they also offer little to illuminate why these corridors were ever traveled in the first place, let alone how one might find different ways of passing through them now. As Annie Coombes urges, "[I]t is only by coming to terms with the heterogeneity of responses" to representations of colonial subjects and cultures proffered by exhibitions "that we can fully comprehend the insidious appeal of colonial ideology, even amongst those philanthropic and humanitarian 
liberals who were its most ardent critics" (2). The Secret Agent, I have been suggesting, calls for just such a reading, which turns away from London's exhibition culture but not without leaving enough of its faint contours for others to trace within the novel's ironic frames. If this is the bid for the rearticulated inclusiveness that Said says marks modernist irony, one of its inclusive gestures is to stage an absent curiosity that implies that there may yet be windows in London that do more than look inward. To be sure, curiosity's ambivalence is not necessarily immune to imperial ideology's advances; a response born out of curiosity might easily become a fetishistic gaze at exhibition spectacles, and Conrad leaves open the question of how curiosity might be enlisted as a tactic for transforming late imperial metropolitan culture. It is in search of a more fully articulated explanation that we now turn to Forster.

The Magic of the Real: Forster at the British Empire Exhibition

During the summers of 1924-25, exhibitors at Wembley held what turned out to be London's last grand spectacle of imperial dominance, an exhibition that, perhaps unsurprisingly, has gone down in history as inadvertently emblematizing conflicted domestic public opinion on empire at its height. ${ }^{10}$ On the one hand, the British Empire Exhibition was a desperate bid to revitalize an imagined community of Britain and its colonies, a fact not lost on journalists and satirists of the day. On the other, it was enormously popular, and its success largely rested on perfecting the art of staking a colonial exhibition's identity on its spectacles of cultural and technological superiority. The Wembley exhibition was particularly adept at fusing commodity display and technological prowess, a fusion best illustrated when thousands gathered to see George $\mathrm{V}$ open the exhibition by pressing a golden globe that acted as the simultaneous symbol of the global flow of British capital and the mechanism for telegraphing British colonies around the world the king's official announcement that the exhibition had begun. But the event's greatest technological feat was to construct in a short period a number of buildings and pavilions modeled after those found in the colonies. Wembley's 27 million visitors-four times as many as the Great Exhibition of 1851—could walk through a fantasyland made to suggest the sweep of British colonial acquisitions, from South African coal mines to East Asian pagodas. For one of these visitors, the Prince of Wales (who also helped design the event), such structures rendered the British Empire Exhibition London's greatest vista in Conrad's sense of the term: it was, as Prince Edward succinctly put it, "the Empire's shop window" (qtd. in Brendon 338).

A visitor with a different view was E. M. Forster. As the correspondent for The Nation and Athenaeum, Forster arrived on April 15, 1924, and, as befits the author of novels of great muddles, he proceeded through "the wrong entrance, or at all events not the right one, which I could not find, and I feared to be turned back by 
the authorities, but they seemed a bit lost too" ("Birth" 43). The confusion may be excused, however, for the king's grand opening to the public would not take place for another week, and much of what Forster relays in "The Birth of an Empire" are the final preparations in advance of that opening. Still, it is tempting to read Forster's review today_ "filled with a fine irritation," as Lionel Trilling noted (142) —as auguring Wembley's dubious successes. Playing down the engrossing features of the exhibition, Forster instead affirms experiences of standing in a barrage of hollow spectacles and empty entertainments: "[B]eauty always does have a rough time in these shows-even rougher than in the actual world" ("Birth" 47). Where official guidebooks promise interesting spectacles and grand amusements, Forster's eye falls on the artificial, undemanding, and underwhelming. After passing through one of the exhibition's large collections buildings (and finding it unimpressive), he at last reaches his destination at the section devoted to British India, where he cannot resist a backhanded compliment of the section's realism. "Indians smiled charmingly, and gave incorrect information. It was all delightful; indeed, nothing was wanting except a few more exhibits" (46).

Yet amid this very scene something unlikely happens. Strolling past a series of Indian exhibits, Forster finds himself caught off guard by a miniature of a famous site in Lahore, the Wazir Khan Mosque, a structure Forster likely saw for himself in 1912. ${ }^{11}$ As he writes in his review, the small object "was so lovely and stood so incidentally and accidentally upon a table, that it had all the magic of a real building, met by chance among squalid or pretentious streets" (46). Though he might have commented on the craftsmanship or verisimilitude of the miniature, he writes instead that the artifact seized his attention because of its accidental, careless placement-a quality Forster knew would not survive the exhibition's opening, and perhaps not the hour. "When I see it next," he laments, "it will probably be glassed, docketed, and have lost its preternatural charm" (46). But it is clear that what excites Forster has as much to do with the object's "lovel[iness]"-its unaffected, arresting beauty—as with its "magic," its uncanny ability to mimic the excitement of a discovery outside an exhibition because of its artless display. For the moment the solicitous staging that characterizes the genre of exhibition display is yet to come. The miniature mosque has been set aside, where it awaits its careful placement within the armature of display whose very absence permits Forster his imaginative encounter with the model's referent. The impact of this absence for Forster becomes more clear when compared with the collections building he has just mentioned passing through on his way to the British Indian exhibits. Though the immense concrete structure has been designed to impress visitors with its magnitude and swelling collection of artifacts, for Forster it was "so large that it failed in the normal immunities of an interior" (44). It is as though the vastness of the space and the depth of the collections that had been calculated to make the structure appear imposing have instead rendered the space contrived and unreal.

11 Forster visited Lahore in November 1912, and though he never mentions the Wazir Khan in his letters or in the travel journals collected in The Hill of Devi, he would likely have seen it when friends living in Lahore took him sightseeing (Furbank 1:228-33). 
On the one hand, we can read Forster as turning the affective force of his imaginative sojourn against the exhibition that sponsors it. This misplaced miniature stands out because the rest of the exhibition's artifice draws unwelcome attention to itself. The immense exercise of pulling the Wembley exhibition together, Forster suggests, is but little compared with the extraordinary cultural labor demanded of turning representations of empire's grisly entanglements into amusements and rationalizations. All this work cannot help but make the very opposite point that the exhibition's planners sought to advance: rather than being dazzled by the representational power of the exhibition, Forster responds to the magic of a small, cast-aside object. But on the other hand, the exhibition proves more effective, and affecting, than Forster gives it credit. Though he crosses the thresholds of the collections building as a journalist, he becomes a visitor to an imaginary Lahore during his encounter with the small mosque. For all the underplayed liberalism of Forster's article, the exhibition has had its intended effect, albeit in a limited sense, when he imagines himself a tourist in a colonial city. This raises questions about what kind of curiosity Forster's narrative confesses. If this magic arises from the unexpected sense of the real, as Forster suggests, one wonders if this "real" is meaningfully different from the claim made in the exhibition's official guidebook that the miniatures of northwest India intend to demonstrate that "the interest in realms lying over the borders of civilization is very real" (Lawrence 63).

In writing of the small mosque, Forster perhaps unwittingly echoes one of the principal characters in the novel he had completed earlier the same year. We need turn only briefly to A Passage to India (1924) to recall why Adela Quested repeatedly pleads at the beginning of the novel, "I want to see the real India" $(22,25)$, and to note the implications of such a plea for Forster's Wembley exhibition review. As a number of the novel's readers have noticed, casting Adela as an English tourist in India restages Forster's own travels there in 1912-13 and 1921-22, a repetition that invites us to note the resemblances and disparities between the author and the character. ${ }^{12}$ Like Forster, Adela arrives in India with more than idle interest, for as the fiancée of a colonial official she is aware that she is likely to remain there for some time; she is, in her own words, not "just a globe-trotter" (31). But Adela's earnest interest manifests itself as the naive will to understand a culture by gazing upon an archive of alterity that includes Indian people, artifacts, and locations, a naïveté that will eventually, and tragically, lead her to the local tourist destination of the Marabar Caves. Leading up to that visit, Forster captures Adela's credulity in her willingness to mistake Dr. Aziz, literally the first Indian she meets, for the embodiment of the colony itself. "In her ignorance, she regarded him as 'India,' and never surmised that his outlook was limited and his method inaccurate, and that no one is India" (76). Such ignorance is hardly idiosyncratic, and Forster's novel carefully traces just how difficult it can be even for the well-intended to break from the long history of institutionalized racism, purported cultural superiority, and imperial ideology that supplies colonial rule with its authority. It is in her eagerness "to see the real India" - that is, her belief that its essence could be visually conin Out of Place (101-34). 
sumed if only she could shove aside the obscuring infrastructure of British colonial rule-that Adela elides Aziz with what Forster's narrator dubs the reduced, homogenized "India" that lives only between quotation marks. Put another way, we might say Adela mistakes India for Aziz's exhibition of Indianness.

In performing a kind of Indian subjecthood, Aziz is also, at least for the moment, willing to oblige his English visitors with what they want, and in seeking to supply the view Adela hopes to find, he invites her to visit his home. This invitation, which Aziz extends at a significant early scene in A Passage to India, is more polite than earnest, and one he immediately regrets. No sooner is his invitation spoken than Aziz and Adela are led into Fielding's eighteenth-century garden house, a home that makes Aziz recall his own as "a detestable shanty near a low bazaar" (73). In lieu of rescinding the invitation to his bungalow, Aziz begins to praise Fielding's garden house as one of Chandrapore's most impressive private interiors. But a tourist as inquisitive and persistent as Adela will not settle for an Anglo Indian abode, whether or not Aziz assures her that when one is in Fielding's home "you are in India; I am not joking" (73). When she promises once more to visit his home, Aziz makes his final bid: "He thought again of his bungalow with horror. ... What was he to do? 'Yes, all that is settled,' he cried. 'I invite you all to see me in the Marabar Caves'" (79).

In the space of a few pages, Forster's novel announces a strategy it will adopt throughout for negotiating its sense of the real by shuttling between three sites offered to fulfill Adela's quest. By moving from Aziz's "shanty" to Fielding's splendid garden home and arriving, finally, at the caves that must substitute for both homes as a location for a tourist's inspection of "the real India," Forster plots a course through Chandrapore that moves from the common to the stately and ultimately to what is outside the city and only partly comprehensible. Adela's curiosity might have been disappointed by Aziz's home (had she visited it) just as it was piqued by Fielding's, but it certainly finds its limits in her horrifying encounter in the caves. Rather than marking any single location as a synecdoche for the real, the text assigns significance to mobility between and through these locations, a point Forster underscores both by making these the locations to which his narrative will frequently return and by dividing the novel into three distinct parts: "Mosque," "Caves," and "Temple." In this way, A Passage to India does more than suggest that meaningful experience sometimes stands in excess of an accessible, readable, and viewable reality; the novel also traces a cautionary tale for liberal humanist curiosity ${ }^{13}$ Forster acknowledges Adela's curiosity as rooted in genuine interest in, and concern for, India's colonial subjects and yet simultaneously reveals her curiosity to be doomed by the form it takes: the detached tourist's gaze that prevents her from seeing the complex, contested, and plural India that the novel presents as a journey through distinct Indian locations.

As we have begun to notice, Forster rehearses a similar three-part tour in his review of the Wembley exhibition, reporting by turns in "The Birth of an Empire"

can't avoid bad break here w/o loose line. -comp
13 Curiosity is one-quarter of Forster's conception of humanism, whose three other characteristics - "a free mind, belief in good taste, and belief in the human race"-Forster also invests in Adela (qtd. in Sprott 75). 
from the exhibition's London address, the ersatz India temporarily installed there, and the India of Forster's memory. In this text, however, Forster cannot duplicate in London the passage between discreet boundaries that his novel plots through India. On the contrary, his walk through the exhibition becomes most interesting for him precisely when all three locations are intertwined, when he stands in a fabricated colony in the middle of London pretending to be in India as he recalls it. However, Forster follows his comments on the miniature mosque with a conclusion that seeks to disentangle these spaces once more by redrawing the boundaries between exhibition and reality. "Well, it is a show that will suit all tastes. Millions will spend money there, hundreds will make money, and a few highbrows will make fun. I belong to the latter class. Rule me out; go, think your own thoughts, don't forget your spats, and don't expect an Empire to be born too punctually" (47). Despite his lighthearted tone, Forster's language discloses an eagerness to stride out of the exhibition's gates and secure his return to a London largely untouched by exhibitors. Inhering in these statements is the muted awareness of the networks connecting the exhibition and London that are more penetrating than Forster acknowledges here, for his ironic posture intensely seeks to dismantle the fact that there exists little difference between the kind of seeing demanded within the exhibition and the gaze called upon by spectacles elsewhere in London. Not only is the Wembley exhibition simply the latest in several decades of exhibitions to exalt colonial power and technology, not only does it take place in London in order to intensify that city's status as empire's center, and not only are London's hugely successful colonial exhibitions buoyed by widespread interest to inspect the evidence of British imperialism; in addition to all this, the attraction to spectacles of scientific authority and cultural alterity that London already fosters forms the basis for the genre of display at colonial exhibitions. The exhibitions simply refine that form of seeing, elevating what is ordinary and normalized elsewhere. Exhibitors may strain to present a unified and amusing vision of empire, but Forster's own straining to represent "these shows" as apart from "the actual world" (47) cannot help but uncloak London's presence within the exhibition itself. But even without Forster's acknowledgment, A Passage to India has offered a template for reading the exchange of such spaces and the views Forster records there as beginning in detachment only to conclude in a gesture of curiosity.

What we learn from Forster's trip to Wembley, and his imaginative sojourn to Lahore, is that although the self-conscious aims of curiosity may not easily be divested from the unconscious gestures of fetishism, their codependence proves instructive. Forster's curiosity emerges from the knowledge acquired by his ironic stance against the exhibition. By treating the miniature mosque not as if it were magical but simply as magical, he writes of the small model as doing the work of a fetish, containing the affective power of that for which it stands as substitute and which is glaringly absent from the exhibition itself-the vibrant and irreducible spaces, buildings, and cultures of colonial India. It is only in ironizing the exhibition that Forster permits himself to experience (and later to disclose) curiosity for one its artifacts. If irony in Forster's hands is the device of distance and return, detachment and reattachment, abandonment and resituation, it is because his texts reserve space for curiosity in irony's company-or, to be more precise, more than 
one space. It is in the plural locations of A Passage to India and "The Birth of an Empire" that Forster's irony not only permits but also encourages the tentative gestures of curiosity, gestures inspired by the urgency of adapting to all that is uncertain and unanticipated in acts of arrival, passage, and departure. This bid for curiosity reaches less for what is to be seen at the exhibition than for what is not on display there. It is a request to know more, more about the Wazir Khan, Islam, Lahore-more about the versions of British India that lie beyond relations with London or empire. It is also a request to know more about London at the zenith of empire, this rich and strange place where Lahore can appear in England just as England has fashioned itself in Lahore. Irony is Forster's means for demarcating the exhibition from the surrounding city, and curiosity is the name for the endeavor to see beyond both locations and their boundaries toward the space where each may yet have something more to show, to narrate, and to offer.

\section{Works Cited}

Anderson, Amanda. The Powers of Distance: Cosmopolitanism and the Cultivation of Detachment. Princeton: Princeton UP, 2001.

Baucom, Ian. Out of Place: Englishness, Empire, and the Locations of Identity. Princeton: Princeton UP, 1999.

Benedict, Barbara. Curiosity: A Cultural History of Early Modern Inquiry. Chicago: U of Chicago P, 2002.

Benjamin, Walter. The Arcades Project. Trans. Howard Eiland and Kevin McLaughlin. Cambridge: Harvard UP, 1999.

Brendon, Piers. The Decline and Fall of the British Empire, 1781-1997. New York: Knopf, 2008.

Cohen, Scott. "The Empire from the Street: Virginia Woolf, Wembley, and Imperial Monuments." Modern Fiction Studies 50 (2004): 85-109.

Conrad, Joseph. The Secret Agent: A Simple Tale. 1907. New York: Modern Library, 2004.

Conroy, Mark. Modernism and Authority: Strategies of Legitimation in Flaubert and Conrad. Baltimore: Johns Hopkins UP, 1985.

Coombes, Annie E. Reinventing Africa: Museums, Material Culture, and Popular Imagination in Late Victorian and Edwardian England. New Haven: Yale UP, 1994.

The "District Railway" Guide to the Greater Britain Exhibition. London: Boot and Son, 1899.

Forster, E. M. “The Birth of an Empire.” 1924. Abinger Harvest. New York: Harcourt, 1964. 43-47.

The Hill of Devi. New York: Harcourt, 1953.

A Passage to India. 1924. New York: Harcourt, 1984. 
Furbank, P. N. E. M. Forster: A Life. 2 vols. in 1. New York: Harcourt, 1977.

Giddens, Anthony. A Contemporary Critique of Historical Materialism. 2nd ed. Stanford: Stanford UP, 1995.

Gikandi, Simon. Maps of Englishness: Writing Identity in the Culture of Colonialism. New York: Columbia UP, 1996.

Greenhalgh, Paul. Ephemeral Vistas: The Expositions Universelles, Great Exhibitions, and World's Fairs, 1851-1939. Manchester: Manchester UP, 1988.

Harpham, Geoffrey Galt. "Abroad Only by a Fiction: Creation, Irony, and Necessity in Conrad's The Secret Agent." Representations 37 (1992): 79-103.

Harvey, David. The Limits to Capital. Oxford: Blackwell, 1982.

Hoffenberg, Peter H. An Empire on Display: English, Indian, and Australian Exhibitions from the Crystal Palace to the Great War. Berkeley: U of California P, 2001.

Howe, Irving. Politics and the Novel. New York: Horizon, 1957.

Imperial International Exhibition London 1909: Official Guide. Derby: Bemrose and Sons, 1909. Microfilm.

Jameson, Fredric. The Political Unconscious: Narrative as a Socially Symbolic Act. Ithaca: Cornell UP, 1981.

Koenigsberger, Kurt. The Novel and the Menagerie: Totality, Englishness, and Empire. Columbus: Ohio State UP, 2007.

Lawrence, G. C., ed. The British Empire Exhibition 1924: Official Guide. London: Fleetway, 1924.

Logan, Peter Melville. Victorian Fetishism: Intellectuals and Primitives. Albany: State U of New York P, 2009.

Lukács, Georg. The Theory of the Novel. Trans. Anna Bostock. Cambridge: MIT P, 1971.

MacKenzie, John M. "The Popular Culture of Empire in Britain." The Oxford History of the British Empire. 5 vols. Ed. Wm. Roger Louis. New York: Oxford UP, 1999. 4:212-31.

McLaughlin, Joseph. Writing the Urban Jungle: Reading Empire in London from Doyle to Eliot. Charlottesville: UP of Virginia, 2000.

Mitchell, Timothy. "Orientalism and the Exhibitionary Order." Colonialism and Culture. Ed. Nicholas B. Dirks. Ann Arbor: U of Michigan P, 1992. 289-317.

Posnock, Ross. The Trial of Curiosity: Henry James, William James, and the Challenge of Modernity. New York: Oxford UP, 1991.

Pratt, Mary Louise. Imperial Eyes: Travel Writing and Transculturation. New York: Routledge, 1992.

Said, Edward. Culture and Imperialism. New York: Vintage, 1993. 
Sedgwick, Eve Kosofsky. Touching Feeling: Affect, Pedagogy, Performativity. Durham: Duke UP, 2003.

Simmel, Georg. “The Berlin Trade Exhibition.” 1896. Simmel on Culture. Ed. David Frisby and Mike Featherstone. Trans. Sam Whimster. Thousand Oaks: Sage, 1997. 255-58.

Spector, Robert D. "Irony as Theme: Conrad's The Secret Agent." Nineteenth-Century Fiction 18 (1958): 69-71. Rpt. in Conrad: The Secret Agent: A Casebook. Ed. Ian Watt. London: Macmillan, 1969. 166-69.

Sprott, W. J. H. "Forster as a Humanist." Aspects of E. M. Forster: Essays and Recollections Written for His Ninetieth Birthday, January 1, 1969. Ed. Oliver Stallybrass. New York: Harcourt, 1969. 73-80.

Stagl, Justin. A History of Curiosity: The Theory of Travel 1550-1800. Amsterdam: Harwood Academic, 1995.

Thacker, Andrew. “'Mad after Foreign Notions': Ezra Pound, Imagism, and the Geography of the Orient." Geographies of Modernism: Literatures, Cultures, Spaces. Ed. Peter Brooker and Andrew Thacker. New York: Routledge, 2005. 31-42.

Trilling, Lionel. E. M. Forster. New York: New Directions, 1965.

Walkowitz, Rebecca L. Cosmopolitan Style: Modernism beyond the Nation. New York: Columbia UP, 2006.

Watt, Ian. Conrad in the Nineteenth Century. Berkeley: U of California P, 1981.

Wilson, A. N. After the Victorians: The Decline of Britain in the World. New York: Picador, 2005.

Wollaeger, Mark. Joseph Conrad and the Fictions of Skepticism. Stanford: Stanford UP, 1990.

Modernism, Media, and Propaganda: British Narrative from 1900 to 1945. Princeton: Princeton UP, 2006.

Zimring, Rishona. “Conrad's Pornography Shop." Modern Fiction Studies 43.2 (1997): 319-48. 